\title{
Cure Characteristics and Mechanical Properties of Pineapple Leaf Fibre Filled Natural Rubber
}

\author{
Chinenye C. Ekwueme*, Isaac 0. Igwe \\ Department of Polymer and Textile Engineering, Federal University of Technology, Owerri, Nigeria \\ Email: *chinenyecharity10@gmail.com, zik3gh@gmail.com
}

How to cite this paper: Ekwueme, C.C. and Igwe, I.O. (2018) Cure Characteristics and Mechanical Properties of Pineapple Leaf Fibre Filled Natural Rubber. Journal of Minerals and Materials Characterization and Engineering, 6, 601-617.

https://doi.org/10.4236/jmmce.2018.66043

Received: August 21, 2018

Accepted: November 19, 2018

Published: November 23, 2018

Copyright $\odot 2018$ by authors and Scientific Research Publishing Inc. This work is licensed under the Creative Commons Attribution International License (CC BY 4.0).

http://creativecommons.org/licenses/by/4.0/

\begin{abstract}
The cure characteristics and mechanical properties of natural rubber filled with pineapple leaf fibre (PLF) were studied at different filler contents and particle sizes. The PLF was characterized for filler properties while carbon black (N330) served as the reference filler. The natural rubber vulcanizates were compounded on a two-roll mill. Results showed that PLF $(300 \mu \mathrm{m})$ filled natural rubber vulcanizates exhibited the highest maximum torque $\left(\mathrm{T}_{\max }\right)$ (47.04 lb-in) at filler content, $10 \mathrm{phr}$ among the filler particle sizes investigated. The minimum torque $\left(\mathrm{T}_{\min }\right)$ of the vulcanizates generally increased with the increase in filler contents and particle sizes. The scorch times of the rubber vulcanizates did not vary with fibre content while the cure times of PLF $(300 \mu \mathrm{m})$ filled rubber vulcanizates decreased with filler content. The tensile strength (TS) of PLF $(150 \mu \mathrm{m})$ filled natural rubber vulcanizates generally increased with the increase in filler content whereas the tensile modulus of the rubber vulcanizates decreased steadily with increasing filler particle size at filler contents, 5 and $30 \mathrm{phr}$. The elongation at break (EB) of the rubber vulcanizates exhibited no general order of variation with filler content and particle size, and was generally greater than that of unfilled natural rubber. The flexural strength of the rubber vulcanizates increased with increasing filler particle size at filler contents, 20 and $40 \mathrm{phr}$. The addition of PLF and carbon black improved the compression strength of the rubber vulcanizates, and which for PLF $(300 \mu \mathrm{m})$ and CB fillers generally increased with the increase in filler content. The study has demonstrated the enhancement of properties of natural rubber vulcanizates on incorporation of PLF into natural rubber, however, the property enhancements obtained were less than those recorded for $\mathrm{CB}$ filled natural rubber vulcanizates.
\end{abstract}

\section{Keywords}

Natural Rubber, Pineapple Leaf Fibre, Carbon Black, Mechanical Properties, Cure Characteristics 


\section{Introduction}

The past decades have witnessed increasing interest in the use of rubber products. Rubbers which are elastomers are not used as neat polymers due to lack of hardness, strength properties and wear resistance [1]. They have also being found to degrade or change their properties in the presence of air, light and at elevated temperature [2]. Auxiliary materials called additives are therefore added to rubber during manufacture to improve its processing and application properties of the vulcanizates. One of the most important additives and the second largest following the base polymer in rubber compounding is the filler. Carbon black is the most important reinforcing filler used in the rubber industry. However, because of its origin from petroleum, it causes pollution and gives the rubber a black colour. The filler is also costly [3] [4]. The minerals sepiolite, kaolin, and precipitated silica had been used with little success in the rubber industry as they impacted lower reinforcing properties to rubber in addition to not being compatible with polymer matrices.

A number of inorganic and natural fillers from renewable resources have been investigated for possible use in the rubber industry and are documented in the literature. Thus, Anserifer et al. [5] reinforced natural rubber with precipitated amorphous white silica and reported that the hardness, tensile strength and compression set of the vulcanizates were improved on incorporation of the filler into rubber but that the tear strength, elongation at break, and cyclic fatigue life of the vulcanizates were adversely affected. Clay was used by Kim et al. [6] to fill butadiene rubber and reported that the tensile strength and tear strength of the rubber/clay composites were 4.4 times, and 2 times greater than that of unfilled rubber, respectively.

Igwe and Ejim [7] prepared a series of natural rubber-snail shell powder vulcanizates and reported that the hardness of the vulcanizates was marginally increased at high snail shell powder content. However, the specific gravity of the rubber vulcanizates increased with the increase in snail shell powder content. At snail shell powder content above $5 \mathrm{phr}$, snail shell powder exhibited good fire retardant property. Talc, nano- $\mathrm{ZnO}$, nano- $\mathrm{CaCO}_{3}$, and nano- $\mathrm{Al}_{2} \mathrm{O}_{3}$ were investigated by Zhang et al. [8] as possible substitute for carbon black in compounding rubber. Their findings showed that the fillers having smaller particle sizes exhibited superior physical and mechanical properties in the vulcanizates than the conventional micro composites. Other inorganic fillers that have been reported to fill rubber were graphite [9] and coal shale [10].

The use of natural fillers from renewable resources to fill rubber is gaining importance among research scientists. These fillers are relatively of low cost, bio degradable, and have fairly high specific modulus. Additionally, composites from these materials have high physico-mechanical properties, are easily recyclable, light in weight, and exhibited high resistance to corrosion and weather changes besides being environmentally friendly [1] [11] [12]. Thus, renewable resources of agricultural origin that have been used to compound rubber in- 
cluded groundnut shell, palm kernel husk, rice husk, coco pod husk and cherry [13] [14] [15] [16]. Similarly, Okoh et al. [17] who investigated the use of Velvet tamarind (VT) seed shell filler in compounding natural rubber and standard Nigerian Rubber $\left(\mathrm{SNR}_{10}\right)$ reported that VT shell filler manifested a reinforcing effect on $\mathrm{SNR}_{10}$ vulcanizates but the reinforcing potential was lower than that of carbon black.

The present paper reports investigation on the use of pineapple leaf fibre in compounding natural rubber. Pineapple leaf fibre has been under investigation in our laboratory as a potential filler for reinforcing polymer products [18] [19] [20]. The fibre was sieved to 75,150 and $300 \mu \mathrm{m}$ mesh sizes, and used at filler contents, 0 - 40 phr. Carbon black was used as the reference filler in this study. The pineapple leaf from where the fibre was extracted is abundant in many orchards and village farms in Nigeria as agricultural waste and has no yet be identified industrial application. Although, Lopattananon et al. [21] studied the utilization of short pineapple leaf fibre in reinforcing natural rubber, the reported work was carried out using pineapple leaf fibre of diameter, $75 \pm 20 \mu \mathrm{m}$ and the properties of the rubber vulcanizates determined were tensile strength, elongation at break and the extent of fibre orientation of the rubber vulcanizates. In the present study, the effects of fibrecontent and particle size on the cure characteristics and mechanical properties of rubber vulcanizates were investigated and the mechanical properties determined were tensile strength, tensile modulus, elongation at break, compression set, and flexural strength.

\section{Materials and Methods}

The natural rubber crumbs conforming to Nigerian Standard Rubber (NSR) grade 10 was obtained from Integrated Rubber Products PLC, Benin, Nigeria. Carbon black (N330) filler used in this study was obtained from Campal Scientific and Technology Co., Onitsha, Nigeria. The vulcanizing materials such as zinic oxide, accelerator (MTBS), activator (TMQ), sulphur, stearic acid were kindly supplied by Dunlop PLC, Lagos, Nigeria. Processing oil was purchased from a chemical store at Onitsha, Nigeria. Pineapple leaves from which the fibre was prepared were collected from a pineapple orchard at Umuagwo, Owerri, Nigeria. The fibre was sieved to three particle sizes, namely, 75, 150, and $300 \mu \mathrm{m}$ respectively, and characterized for the following filler properties: $\mathrm{pH}$ (ASTM D 1512-05), moisture content (ASTM D 1509-12), weight loss on ignition (ASTM D 1509-13), oil absorption (ASTM D 1510, 1983), iodine adsorption and specific gravity according to standard procedures. The chemical composition of pineapple leaf fibre was determined as follows.

\section{1) Ash Content}

\section{Procedure (ASTM D 4607-94)}

$5 \mathrm{~g}$ of dry pineapple leaf fibre was placed in a cleaned dry crucible with cover, and burnt directly over a low flame of Bunsen burner until it was carbonized. The crucible with its content was placed in a muffled furnace at $55^{\circ} \mathrm{C}$ for $4 \mathrm{~h}$ to 
burn off all the carbon. The crucible was later removed from the furnace, the cover was replaced and the crucible was later placed in a dessicator, and cooled to room temperature. The ash content was calculated as;

$$
\text { Total ash }(\%)=\frac{\text { Weight of fibre residue after burning }}{\text { Initial weight of dry fibre }} \times \frac{100}{1}
$$

\section{2) Cellulose Content}

Procedure (Georing and van Soest, 1970) [22].

$1.5 \mathrm{~g}$ of pineapple leaf fibre (PLF) was placed in a $300 \mathrm{~cm}^{3}$ beaker, and $75 \mathrm{~cm}^{3}$ of $17.5 \%$ of $\mathrm{NaOH}$ was added. The contents of the beaker were stirred with a glass rod. After stirring, the stirrer was raised and the fibre adhering on the rod was removed using a pointed glass rod. The stirrer was raised with $25 \mathrm{~cm}^{3}$ of $17.5 \% \mathrm{NaOH}$ solution, and this was added to the beaker. The beaker with its content was placed in a water bath maintained at $25^{\circ} \mathrm{C} \pm 0.2^{\circ} \mathrm{C}$. After a period of $30 \mathrm{~min}, 100 \mathrm{~cm}^{3}$ of distilled water was added to the beaker, and the beaker was allowed to stay for another $30 \mathrm{~min}$ in the bath. At the expiration of $30 \mathrm{~min}$, the content of the beaker was stirred with a glass rod and transferred to a filtration funnel; the first $20 \mathrm{~cm}^{3}$ of the filtrate was discarded. $25 \mathrm{~cm}^{3}$ of the filtrate was pipetted into a $250 \mathrm{~cm}^{3}$ conical flask and $10 \mathrm{~cm}^{3}$ of $0.5 \mathrm{M}$ potassium dichromate was added. The solution was allowed to remain for $15 \mathrm{~min}$ after which $50 \mathrm{~cm}^{3}$ of distilled water was added to it. The flask was allowed to cool to room temperature after which 4 drops of ferrous indicator was added to the content, and then titrated with $0.1 \mathrm{M}$ ferrous ammonium sulphate solution to a purple colour. A blank titration was made where the fibre was substituted with $12.5 \mathrm{~cm}^{3}$ of $17.5 \%$ $\mathrm{NaOH}$ and $12.5 \mathrm{~cm}^{3}$ of water. The $\alpha$-cellulose content in the fibre was calculated as:

$$
\alpha \text {-cellulose }(\%)=\frac{100-6.85\left(V_{2}-V_{1}\right) \times M \times 20}{A \times W}
$$

where $V_{2}=$ Volume of ferrous ammonium sulphate used in sample titration $\left(\mathrm{cm}^{3}\right), \mathrm{V}_{1}=$ Volume of ferrous ammonium sulphate used inblank titration $\left(\mathrm{cm}^{3}\right)$, $\mathrm{M}=$ Molarity of ferrous ammonium sulphate, $\mathrm{W}=$ Weight of dry pineapple leaf fibre $(\mathrm{g})$ and $\mathrm{A}=$ Volume of pineapple fibre used in the oxidation $\left(\mathrm{cm}^{3}\right)$.

\section{3) Lignin Content}

The acid-insoluble lignin was determined according to the method of Liyama and Wallis [23] with minor modifications.

\section{Procedure}

The dry pineapple leaf fibre (PLF) was pulverized in a mill, and successively extracted with $50 \%(\mathrm{v} / \mathrm{v})$ toluene in ethanol twice, $95 \%(\mathrm{v} / \mathrm{v})$ ethanol once, and water once. The resulting extractive-free fibre was rinsed with acetone and dried in a Lohconco rapid evaporator. $4 \mathrm{mg}$ of the dried meal was digested in $1.25 \mathrm{~cm}^{3}$ of $25 \%(\mathrm{v} / \mathrm{v})$ perchloric acid at $70^{\circ} \mathrm{C}$ for $30 \mathrm{~min}$. The reaction mixture was diluted to a final volume of $25 \mathrm{~cm}^{3}$ with acetic acid and $5 \mathrm{~cm}^{3}$ of $2 \mathrm{M} \mathrm{NaOH}$.

The absorbance of the solution was spectrophotometrically determined at 280 
nm. The lignin content (acid-insoluble) was calculated using the absorption coefficient on the basis of extractive free material.

\section{4) Hollocellulose Content}

Procedure (Goering and van Soest) [22]

$80 \mathrm{~cm}^{3}$ of hot distilled water, $0.50 \mathrm{~cm}^{3}$ of acetic acid, and $1 \mathrm{~g}$ of sodium chlorite were added to $2.5 \mathrm{~g}$ of PLF contained in $250 \mathrm{~cm}^{3}$ conical flask. The mixture was covered, and heated on a water bath at $70^{\circ} \mathrm{C}$ with occasional stirring. After $1 \mathrm{~h}$, $0.5 \mathrm{~cm}^{3}$ of acetic acid, and $1 \mathrm{~g}$ of sodium chlorite were added. The addition of 0.5 $\mathrm{cm}^{3}$ of acetic acid, and $1 \mathrm{~g}$ of sodium chlorite was repeated after $1 \mathrm{hr}$ interval for the next $5 \mathrm{~h}$ after which the sample was left in the water bath overnight.

After $24 \mathrm{~h}$, the holocellulose formed was filtered on a fritted disc glass thimble with acetone, oven dried at $105^{\circ} \mathrm{C}$ for $24 \mathrm{~h}$, then placed in a dissicator for $1 \mathrm{hr}$, and weighed.

\section{Compounding of Natural Rubber Vulcanizates}

The ingredients used in compounding natural rubber are given in Table 1. A two-roll mill was used in the compounding process.

\section{The Curing Process}

The curing of the compounded rubber was carried out on a hydraulic machine (hot press) with electrically heated platens whose temperature was set at $130^{\circ} \mathrm{C} \pm 2^{\circ} \mathrm{C}$. The moulds were preheated to attain the platen temperature and the compounded rubber was cut to the shape of the mould and placed in the between the platens at a pressure of 33.4 bars for 8 to $10 \mathrm{~min}$, after which the cured sample was removed from the mould. The cure characteristics for the vulcanization of the rubber recipes were determined using the Oscillating Disc Rheometer 100S in accordance the ISO 3417 method.

The ingredients are arranged in the order in which they were added during rubber compounding with the accelerator and soluble sulphur being added at the same time and lastly too.

Tests on natural rubber vulcanizates were performed as follows.

\section{1) Tensile Testing (ASTM D 412-87)}

The tensile strength of the rubber vulcanizates were measured using a Monsanto tensile tester 3369 having a cross head speed of $500 \mathrm{~mm} / \mathrm{min}$. Dumbbell shaped specimen $(30 \times 4 \times 2 \mathrm{~mm})$ of the rubber vulcanizates were used for the tests. The elongation at the break was calculated from the tensile strength at break. The recorded value of each tensile parameter is the average of three measurements.

\section{2) Compression Set}

\section{Procedure (ASTM D 395-03 1983)}

The compression set of the cured rubber vulcanizates were determined using a compression set machine (Wallace Machine, Model C84025/2) having a disc sample of thickness, $2.3 \mathrm{~mm}$ and diameter, $2.5 \mathrm{~mm}$. The rubber vulcanizates were placed in the compression parallel plate and compressed to spacethickness 
$\left(\mathrm{T}_{2}\right)$ with a force of $145 \mathrm{~N}$ at a temperature of $70^{\circ} \mathrm{C}$. The compression set of the samples was calculated as the difference in the original thickness of the specimen $\left(\mathrm{T}_{0}\right)$ and the thickness after the distorted load was removed $\left(\mathrm{T}_{1}\right)$, and allowed to recover for $30 \mathrm{~min}$.

\section{3) Flexural Test}

Three-point bending flexural testing was performed on the vulcanizates using an Instron tester 3369 at $23^{\circ} \mathrm{C} \pm 2{ }^{\circ} \mathrm{C}$ and $50 \% \pm 5 \%$ relative humidity in accordance to ASTM D 790 with a support span length of $50 \mathrm{~mm} / \mathrm{min}$. Five measures were carried out on each test sample and the average values was calculated.

\section{Results and Discussion}

\subsection{Analysis of Pineapple Leaf Fibre}

The results of physico-chemical analysis of pineapple leaf fibre are shown in $\mathrm{Ta}$ ble 2 and Table 3. The loss on ignition for PLF was determined to be $81.80 \%$ while that for CB was $92.80 \%$. The effectiveness of a filler may be measured by the carbon content since the higher the value, the greater is the reinforcing effect. As shown in Table 2, pineapple leaf fibre has a higher moisture content when compared to $\mathrm{CB}$, and this may be attributed to its organic origin. High moisture content in a filler often leads to weak filler-matrix adhesion, hence, poor mechanical strength properties of the vulcanizates [24].

Table 1. Recipe for compounding the natural rubber.

\begin{tabular}{cc}
\hline Ingredient & Content (phr) \\
\hline Natural rubber & 100 \\
Stearic acid & 3.0 \\
Zinc oxide & 3.0 \\
TMQ (antioxidant) & 1.0 \\
Linseed oil & 2.0 \\
Filler (PLF and CB) & Variable $(0,5,10,20,30,40)$ \\
Sulphur & 1.8 \\
MBTS (accelerator) & 1.0 \\
\hline
\end{tabular}

$($ MBTS $)=$ Mercapto benzo thia zolesulphanamide, $(\mathrm{TMQ})=$ 3,2,4-trimethyl-1,2-dihydroquinoline, $\mathrm{phr}=$ parts per hundred of rubber by weight.

Table 2. Physical properties of pineapple leaf fibre and carbon black.

\begin{tabular}{ccc}
\hline Property & PLF & CB (N330) \\
\hline pH of aqueous slurry & 6.85 & 7.00 \\
Moisture content (\%) & 5.22 & 2.40 \\
Loss on ignition $(\%)$ & 1.88 & 92.80 \\
Iodine adsorption number $(\mathrm{mg} / \mathrm{g})$ & 59.10 & 81.24 \\
Ash content $(\%)$ & 10.57 & 6.20 \\
Oil absorption $(\mathrm{g} / 100 \mathrm{~g})$ & $1.80(75 \mu \mathrm{m})$ & 2.83 \\
Density $\left(\mathrm{g} / \mathrm{cm}^{3}\right)$ & $1.96(150 \mu \mathrm{m})$ & 1.80 \\
Particle size range & $2.03(300 \mu \mathrm{m})$ & $30-35 \mathrm{~nm}$ \\
\hline
\end{tabular}


Table 3. Chemical composition of pineapple leaf fibre.

\begin{tabular}{cc}
\hline Constituent & Content (wt. \%) \\
\hline Cellulose & 65.16 \\
Holocellulose & 84.65 \\
Hemicellulose & 19.49 \\
Lignin & 4.28 \\
Ash & 10.57 \\
\hline
\end{tabular}

A higher iodine adsorption number $(81.24 \mathrm{mg} / \mathrm{g})$ was recorded for $\mathrm{CB}$ as compared to $59.10 \mathrm{mg} / \mathrm{g}$ for PLF, an indication that CB has a larger surface area (smaller particle size) than the PLF filler. The surface area of a filler is the most important factor that determines its reinforcing effect [25]. From Table 2, it is evident that PLF is slightly acidic while CB is neutral. Highly acidic fillers produce little reinforcement and are prove to scorching [26]. The ash content of PLF (10.57\%) was higher than that of CB (6.20\%), an indication that the amount of trace elements or foreign matters in PLF was higher in PLF than CB.

Table 2 shows that the amount of oil required to wet $100 \mathrm{~g}$ of $\mathrm{CB}$ is greater than that required for PLF of particle sizes 75, 150 and $300 \mu \mathrm{m}$. Thus, the aggregate structure of CB is greater than that of PLF of sizes 75,150 and $300 \mu \mathrm{m}$ by about $1.03,0.87$ and $0.80 \mathrm{~kg}$ respectively.

The density $\mathrm{pH}$ of PLF was determined to be 2.67 while that for CB is 1.80 . The density of PLF is higher than the values reported for other plant fibres like coconut $\left(1.150 \mathrm{~g} / \mathrm{cm}^{3}\right)$, sisal $\left(1.50 \mathrm{~g} / \mathrm{cm}^{3}\right)$ and banana $\left(1.35 \mathrm{~g} / \mathrm{cm}^{3}\right.$ [27] [28].

The chemical composition of PLF as given in Table 3 shows the presence of appreciable quantity of cellulose and generally, the greater the cellulose content, the better is the quality of vulcanizates produced using the material [29]. The cellulose content of the fibre is $65.16 \%$. Cellulose is the component that makes the fibre of non-wood materials to be stronger and tougher [30].

\subsection{Cure Characteristics of Natural Rubber Vulcanizates}

\subsubsection{Scorch Time}

The scorch times $\left(t_{s 1}\right)$ of the prepared natural rubber vulcanizates illustrated in Figure 1 did not show any clear cut order with increases in fibre content. However, for PLF $(150 \mu \mathrm{m})$, after the initial increase in $t_{s 1}$ on addition of $10 \mathrm{phr}$ of the fibre, $t_{s 1}$ decreased with increases in PLF content. The observe decrease of $t_{s 1}$ with filler content maybe attributed to filler related parameters such as particle size, surface area, filler surface reactivity and also, to the increase in mixing time resulting in the introduction of the filler into natural rubber [31] [32]. Okoh et al. [17] who worked on Velvettamarid seed shell and CB filled natural rubber vulcanizates reported that the scorch times of the vulcanizates decreased with increasing filler content.

The $t_{s 1}$ of CB filled natural rubber vulcanizates did not show any definite order of variation with $\mathrm{CB}$ content. At $30 \mathrm{phr}$ filler content, $\mathrm{CB}$ filled rubber vulcanizates exhibited higher $t_{s 1}$ than those of PLF filled vulcanizates and this may be 
attributed to the higher surface area, surface reactivity and smaller particlesize of CB filler. The scorch times of the rubber vulcanizates were observed to decrease with increases in filler particle size at filler contents, 10 and $30 \mathrm{phr}$.

\subsubsection{Cure Time}

The variation of cure time of pineapple leaf fibre filled natural rubber vulcanizates with filler content is shown in Figure 2. The cure times of PLF (75, and 150 $\mu \mathrm{m})$ filled natural rubber vulcanizates after the initial increase at 5 phr filler content did not show any general order of variation with increases in filler content, while for PLF $(300 \mu \mathrm{m})$ filled natural rubber, after the initial increase in cure time at 5 phr, the cure times decreased with increases in filler contents and were lower than that of unfilled natural rubber.

The decrease of cure times with filler contents has been reported by many researchers [31] [32] [33]. The CB filled natural rubber exhibited the highest cure time of $7.32 \mathrm{sec}$ at filler content, $30 \mathrm{phr}$. The effect of filler particle size on the cure characteristics of natural rubber vulcanizates appear to depend on the filler content incorporated into natural rubber. The differences in cure times observed in this study may be attributed to the differences in filler properties such as surface area, surface reactivity, and particle size [15] [34].

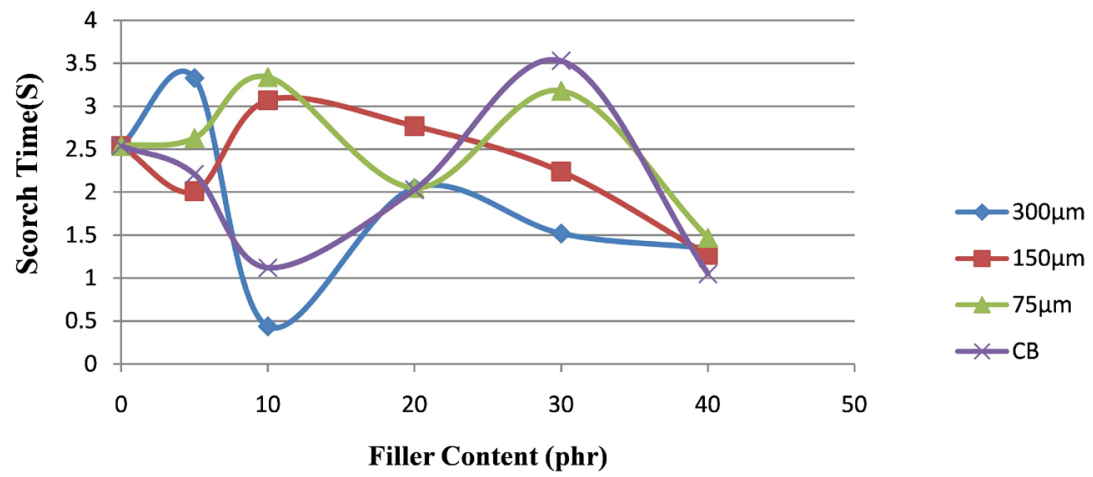

Figure 1. The effects of filler content and particle size on scorch time of filled natural rubber.

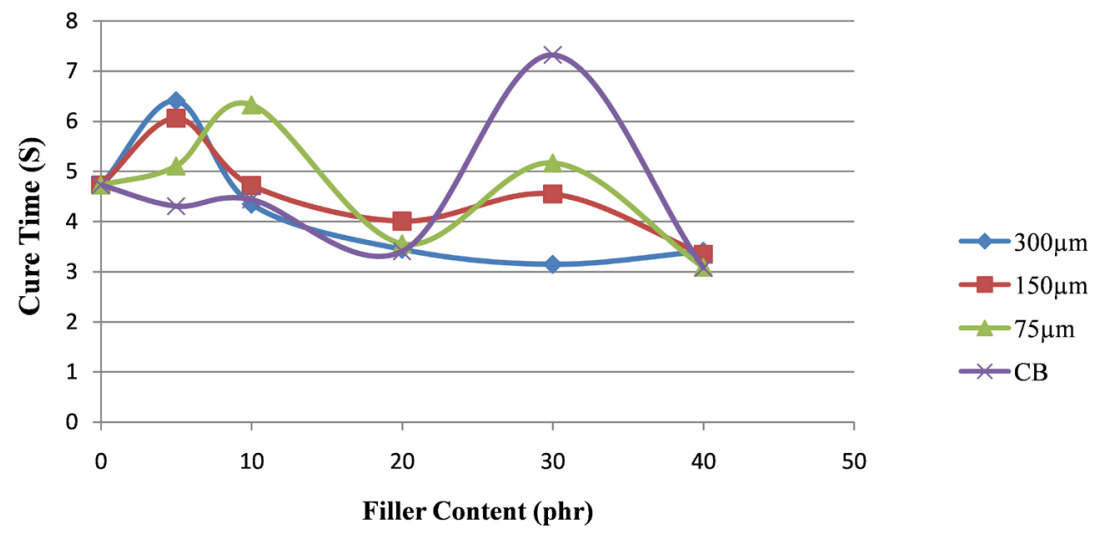

Figure 2. The effects of filler content and particle size on cure time of filled natural rubber. 


\subsubsection{Maximum Torque}

Figure 3 illustrates the variation of maximum torque of pineapple leaf fibre filled natural rubber vulcanizates with filler contents. The PLF $(75$, and $300 \mu \mathrm{m})$ filled natural rubber vulcanizates showed increases in maximum torque $\left(\mathrm{T}_{\max }\right)$ between filler contents, 5 and $10 \mathrm{phr}$, exhibited a decrease in $\mathrm{T}_{\max }$ at $20 \mathrm{phr}$ filler content, with subsequent increases in $\mathrm{T}_{\max }$ with filler content. Osabohien and Egboh [1] who studied cherry seed shell filled natural rubber vulcanizates reported that the maximum torque generally increased with increases in filler content, and that the increases were higher for CB filled rubber vulcanizates.

Generally, PLF $(300 \mu \mathrm{m})$ exhibited the highest $\mathrm{T}_{\max }$ value $(47.04 \mathrm{lb}$-in) in the vulcanizates at filler contents, $10 \mathrm{phr}$ among the filler particle sizes studied. CB exhibited the highest $\mathrm{T}_{\max }$ value ( $35.65 \mathrm{lb}$-in) at $40 \mathrm{phr}$ filler content. The higher $\mathrm{T}_{\max }$ of $47.04 \mathrm{lb}$-in recorded for PLF filled rubber vulcanizates at $10 \mathrm{phr}$ filler content may be attributed to the nature of PLF filler such as surface area, surface reactivity, and particle size [35].

\subsubsection{Minimum Torque}

The changes in minimum torque $\left(\mathrm{T}_{\min }\right)$, a measure of initial viscosity of rubber vulcanizates are illustrated for filled and unfilled rubbers in Figure 4. The figure shows that $\mathrm{T}_{\text {min }}$ increased with increases in filler contents and particle sizes.

The increases in $\mathrm{T}_{\min }$ with filler content are indicative of a good filler-matrix adhesion which restricted the free mobility of the rubber chains. Lopattananon et al. [21] who studied the orientation and mechanical properties of chemically treated PLF/NR composites reported that $\mathrm{T}_{\text {min }}$ was independent of filler content. At any filler content considered, CB filled natural rubber exhibited higher $\mathrm{T}_{\min }$ than PLF filled natural rubber, irrespective of PLF particle size. This may be due to higher surface area, greater rubber-filler interactions and consequently, higher retardation in the mobility of rubber chains in the rubber matrix for $\mathrm{CB}$ filled rubber vulcanizates.

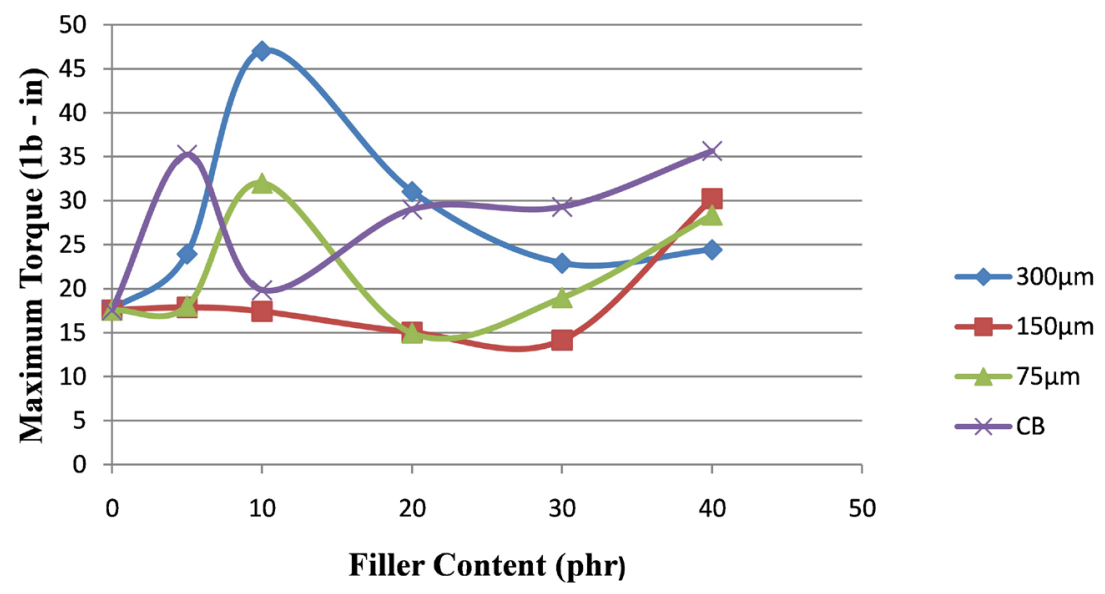

Figure 3. The effects of particle size and filler content on maximum torque of filled natural rubber. 


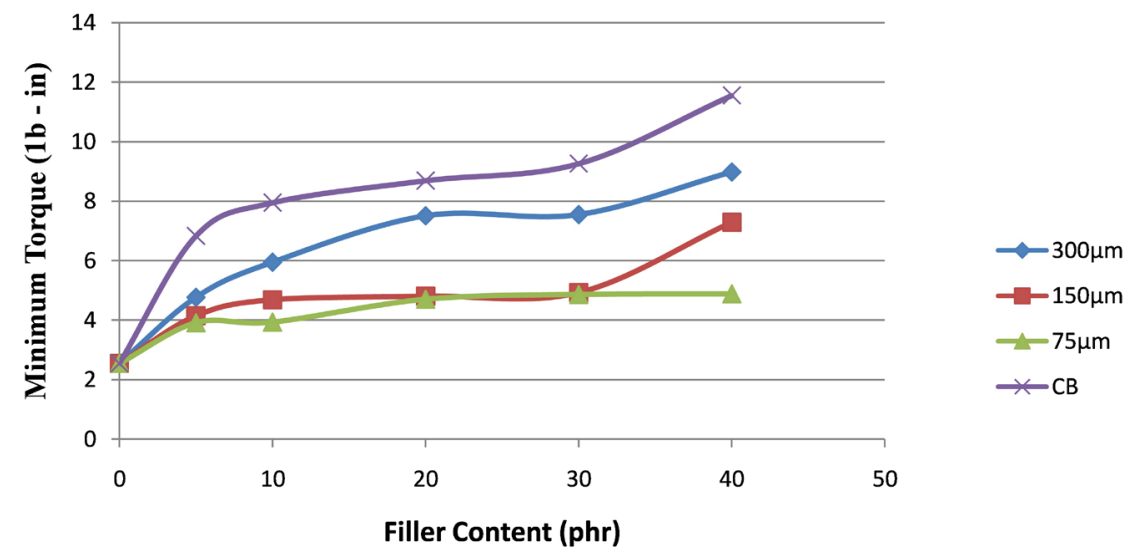

Figure 4. The effects of filler content and partcile size on minimum torque of filled natural rubber.

\subsection{Mechanical Properties of Rubber Vulcanizates}

\subsubsection{Tensile Strength}

The tensile strength of the prepared natural rubber vulcanizates illustrated graphically in Figure 5 shows that the addition of 5 phr PLF $(300 \mu \mathrm{m})$ into natural rubber led to a decrease in the tensile strength of natural rubber after which the tensile strength increased within filler content, 10 to $30 \mathrm{phr}$, and thereafter, decreased at $40 \mathrm{phr}$ filler content. This may be due to the phenomenon of phase inversion and agglomeration effect [36]. The filler agglomeration acts as an obstacle to filler dispersion and this phenomenon increases with increase in filler content which consequently lowers the filler-matrix interactions. This results to a decrease in tensile strength after the optimum amount of filler ( $30 \mathrm{phr}$ ) has been added.

The tensile strength of PLF $(150 \mu \mathrm{m})$ filled natural rubber increased with increases in filler content within the filler content investigated. The tensile strength of $\mathrm{CB}$ filled natural rubber increased with increases in filler content until a maximum strength (13.89 MPa) was reached at $30 \mathrm{phr}$ filler content after which the tensile strength decreased. CB exhibited higher tensile strength than PLF filler at filler content greater than $10 \mathrm{phr}$. The better tensile strength properties of $\mathrm{CB}$ over PLF in the vulcanizates may be due to better bonding quality between $\mathrm{CB}$ and the rubber matrix. Generally, the observed reduction in tensile strength of PLF rubber vulcanizates is due to the incompatibility between the PLF, and rubber matrix resulting to weak rubber-filler interaction. As a result, the filler was not able to support the uniform transmission of stresses from the rubber matrix leading lower tensile strength.

\subsubsection{Tensile Modulus}

Figure 6 shows that the tensile modulus of PLF filled natural rubber at filler content, $30 \mathrm{phr}$ decreased steadily with increases in filler particle size. The PLF filled natural rubber vulcanizates of particle sizes, 75 and $300 \mu \mathrm{m}$ did not exhibit any clear cut order on the variation of tensile modulus with filler content. The 
modulus of $\mathrm{CB}$ filled natural rubber vulcanizates is observed to increase steadily with increasing $\mathrm{CB}$ content, and in all cases, was higher than those of filled (PLF) and unfilled natural rubber vulcanizates. This may be due to the formation of strong bonds with the rubber matrix by $\mathrm{CB}$ and may be due to differences in filler properties. Results from filler characterization in this study shows that $\mathrm{CB}$ filler is not acidic ( $\mathrm{pH} 7.00)$, has higher iodine absorption number $(81.24 \mathrm{mg} / \mathrm{g})$, weight loss on ignition $(92.80 \%)$, and smaller particle size $(30-35 \mathrm{~nm})$, factors which favour greater reinforcement in the vulcanizates than PLF filler. Parkinson [37] and Wagner [38] reported than the modulus of filled vulcanizates can be enhanced by improving the surface area and surface reactivity of fillers, filler dispersion and filler-rubber interaction.

\subsubsection{Elongation at Break}

The elongation at break (EB) of vulcanized natural rubber vulcanizates is illustrated in Figure 7. The figure shows that the EB of unfilled natural rubber vulcanizate is generally greater than those of filled natural rubber vulcanizates. This can be attributed to the adherence of the PLF into the rubber matrix resulting to stiffening of rubber chains, and subsequent hardening of the matrix leading to reduction in rubber ductility [17]. This leads to lower resistance to breakage. Thus, the elongation at break decreased, and the modulus increased. The low elongation at break of the rubber vulcanizates obtained in this study implies that the rubber products would be rigid and are expected to have low hysteresis and heat build-up [17]. The observed decrease in elongation at break of PLF filled natural rubber vulcanizates with filler content is consistent with previously reported works on the variation of elongation at break of natural fibre reinforced rubber with filler content [16] [17] [21].

The incorporation of 10 and $30 \mathrm{phr}$ PLF into the rubber matrix led to increases in EB with increase in PLF particle size. Conversely, the addition of $40 \mathrm{phr}$ PLF into the rubber matrix generally led to decreases in EB with increases in filler particle size. CB filled natural rubber vulcanizate exhibited the highest elongation at break at filler content, $30 \mathrm{phr}$.

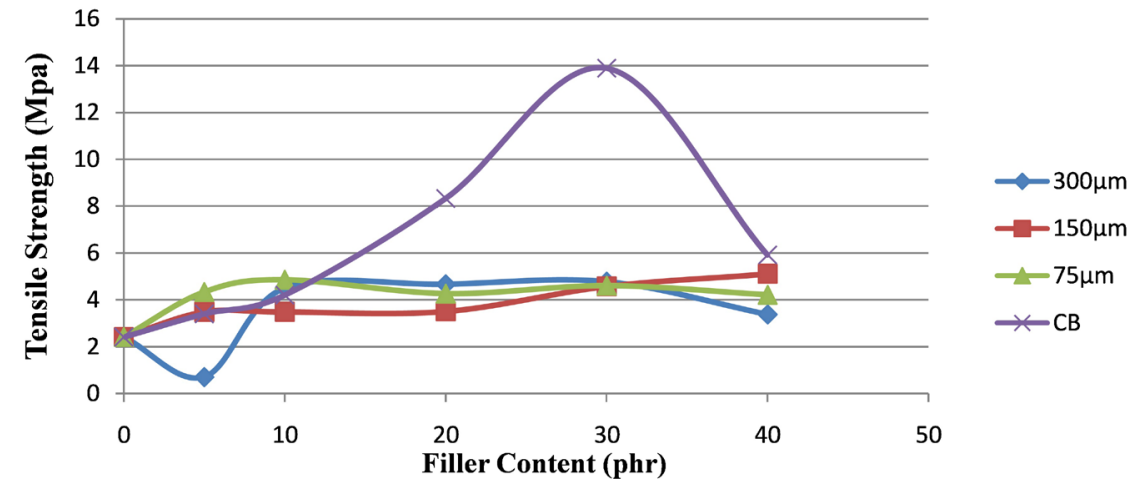

Figure 5. The effects of filler content and pareticle size on tensile strength of filled natural rubber. 


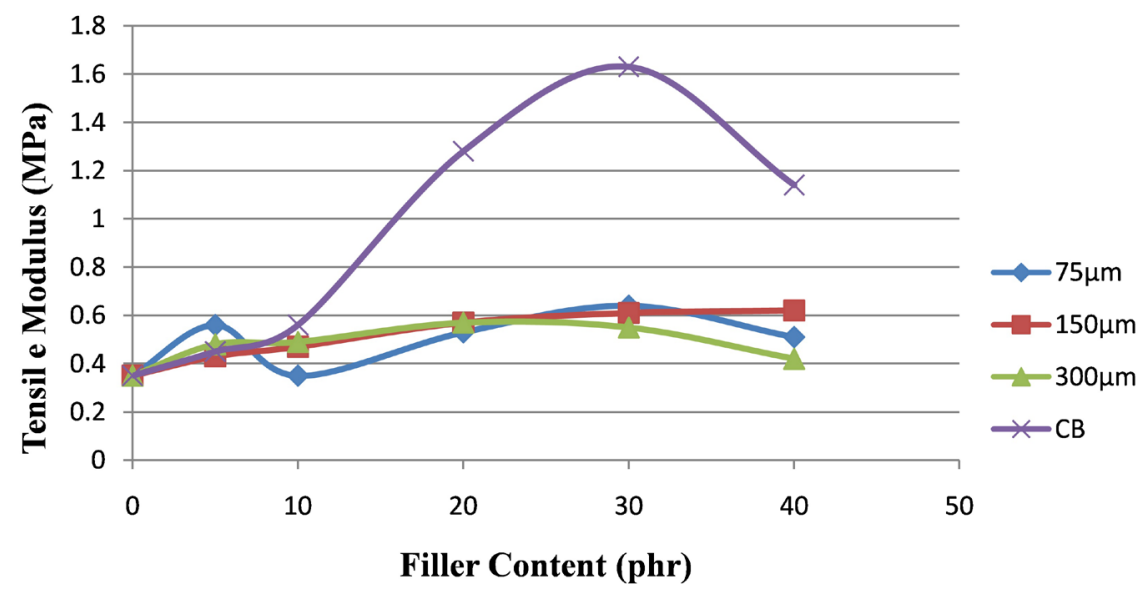

Figure 6. The effects of filler content and particle size on tensile modulus of filled natural rubber.

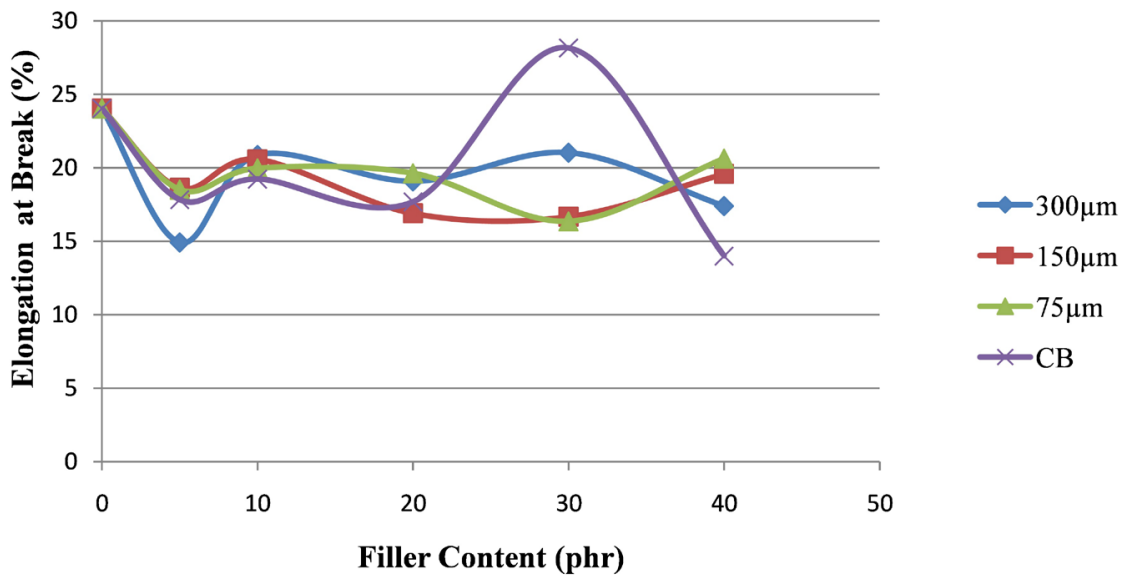

Figure 7. The effects of filler content and particle size on elongation at break of filled natural rubber.

\subsubsection{Flexural Strength}

Figure 8 shows the variation of flexural strength of natural rubber vulcanizates with filler content. PLF $(150 \mu \mathrm{m})$ and CB filled natural rubber generally exhibited higher flexural strength than the unfilled vulcanizate at the filler contents considered.

The flexural strength of PLF $(300 \mu \mathrm{m})$ filled natural rubber vulcanizates should an initial decrease in EB on addition of $5 \mathrm{phr}$ into the rubber matrix but which later, increased with increases in filler content. At filler contents 20 and 40 phr, the flexural strength of rubber vulcanizates increased with increasing filler particle size. $\mathrm{CB}$ filled natural rubber vulcanizates generally exhibited increases in $\mathrm{EB}$ with increases in $\mathrm{CB}$ content.

\subsubsection{Compression Strength}

The compression strength of PLF filled natural rubber vulcanizates as illustrates in Figure 9 did not exhibit any order of variation with filler content and were generally greater than that of unfilled natural rubber. At filler contents $10-30$ 
phr, the compression strength of the rubber vulcanizates did not exhibit any definite order of variation with filler particle size except at $5 \mathrm{phr}$ filler content where the compression strength increased with increase in filler particle size.

While the compression strength of PLF $(300 \mu \mathrm{m})$ filled natural rubber vulcanizates generally increased with increases in filler content ( $5-40 \mathrm{phr})$, those of PLF $(75,150 \mu \mathrm{m})$ filled natural rubber vulcanizates showed decreases at $10 \mathrm{phr}$ content, increased within filler content, $10-40 \mathrm{phr}$ and decreased again at 40 phr filler content. The PLF $(75,150 \mu \mathrm{m})$ exhibited optimum compression strength in the rubber vulcanizates at $30 \mathrm{phr}$ filler content.

The CB filled natural rubber vulcanizates exhibited higher compression strength than PLF filled natural rubber vulcanizates at filler contents, 20 - 40 phr. The findings of this study are in disagreement with the work of Egwaikhide et al. [16] who studied coconut fibre filled natural rubber and reported that unfilled natural rubbervulcanizate had higher compression strength than $\mathrm{CB}$ and coconut fibre filled vulcanizates.

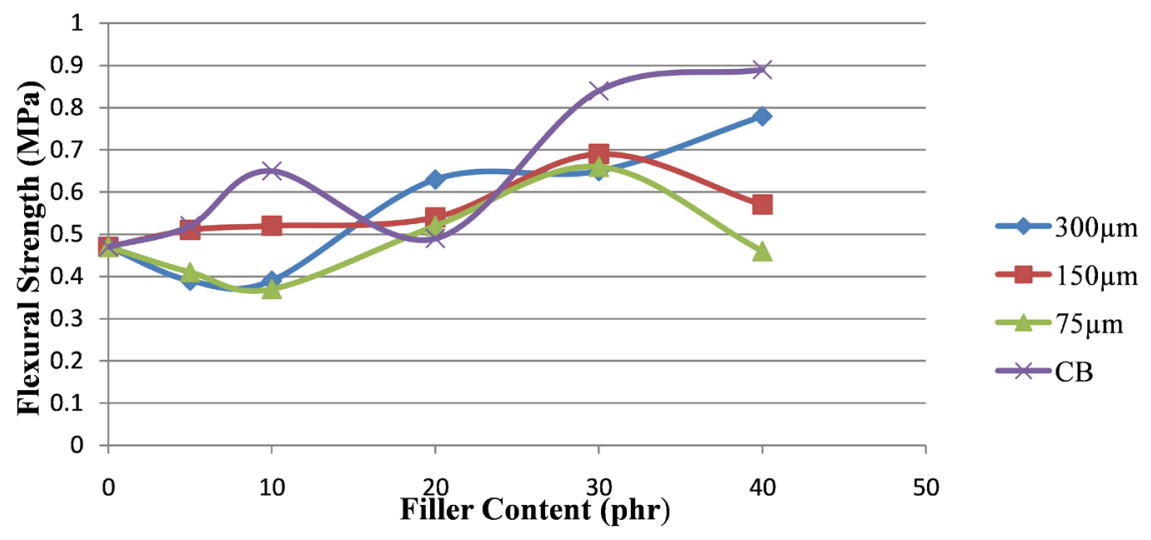

Figure 8. The effects of filler content and particle size on flexural strength of filled natural rubber.

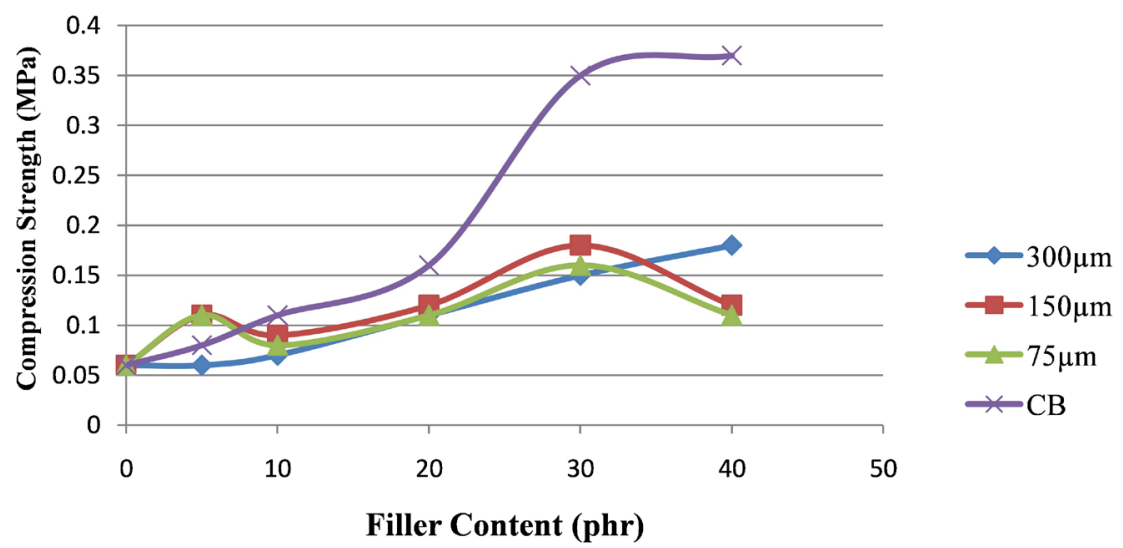

Figure 9. The effects of filler content and particle size on compression strength of filled natural rubber. 


\section{Conclusions}

Pineapple leaf fibre of particle sizes 75, 150 and $300 \mu \mathrm{m}$ has been used successfully to reinforce natural rubber at filler contents, 0 to $40 \mathrm{phr}$. Carbon black was used as the reference filler in this study.

The scorch times $\left(\mathrm{ts}_{1}\right)$ of the natural rubber vulcanizates were observed to decrease with the increase in filler particle size at filler contents, 10 and $30 \mathrm{phr}$ while the cure times of PLF $(300 \mu \mathrm{m})$ filled natural rubber vulcanizates decreased with the increase in filler contents, and were lower that of unfilled natural rubber. PLF $(300 \mu \mathrm{m})$ exhibited the highest maximum torque $\left(\mathrm{T}_{\max }\right)$ value (47.04 lb-in) at filler content, $10 \mathrm{phr}$ among the filler particle sizes studied while $\mathrm{CB}$ exhibited the highest $\mathrm{T}_{\max }$ value (35.65 lb-in) at $40 \mathrm{phr}$ filler content. The minimum torques $\left(\mathrm{T}_{\min }\right)$ of the vulcanizates were observed to increase with the increase in filler content, and particle size.

The PLF $(150 \mu \mathrm{m})$ filled natural rubber vulcanizates exhibited increases in tensile strength with increase in filler particle size. The tensile modulus of PLF filled natural rubber decreased steadily with the increase in filler particle size at filler content, $30 \mathrm{phr}$. The PLF $(75$, and $300 \mu \mathrm{m})$ filled natural rubber vulcanizates ex/hibited no clear cut order on the variation of tensile modulus with filler content.

The elongation at break of unfilled natural rubber vulcanizates was greater than those of filled natural rubber vulcanizates. The flexural strength of PLF (150 $\mu \mathrm{m})$ and $\mathrm{CB}$ filled natural rubber were generally higher than that of unfilled natural rubber. The flexural strength of PLF $(300 \mu \mathrm{m})$ filled natural rubber increased with the increase in filler content within filler content, 10 to $40 \mathrm{phr}$. The compression strength of the rubber vulcanizates were generally greater than that of unfilled natural rubber and at filler content, $5 \mathrm{phr}$, the compression strength increased with the increase in filler particle size.

The addition of PLF into natural rubber improved the mechanical properties of the rubber vulcanizates but the improvements were less than those obtained for CB filled natural rubber vulcanizates. This can be due to the smaller particle size of PLF, higher acidity $(\mathrm{pH})$ and moisture content of PLF. There is a reason to believe that by further reducing the particle size of PLF using modern milling equipment, chemical modification of PLF and use of suitable coupling agent, greater reinforcement of PLF filled natural rubber vulcanizates could be obtained thereby improving the potential of PLF as a filler in the rubber industry.

\section{Conflicts of Interest}

The authors declare no conflicts of interest regarding the publication of this paper.

\section{References}

[1] Osabohien, E. and Egboh, S.H.O. (2007) Cure Characteristics and Physico Mechanical Properties of Natural Rubber Filled with the Seed Shells of Cherry (Chryso- 
phyllum albidum). Journal of Applied Science and Environment Management, 11, 43-48.

[2] Bhatnagar, M.S. (2004) A Text Book of Polymer Chemistry and Technology. Vol. 2, Schand and Co. Ltd., New Delhi, 1-138.

[3] Arroyo, M., Lopez-Manchado, M.A. and Herrero, B. (2003) Organo-Montmorillonite as Substitute for Carbon Black in Natural Rubber Compounds. Polymer Science Journal, 44, 2447-2453.

[4] Ismail, H., Rozman, H.D., Jaffri, R.M. and MohdIshak, Z.A. (1997) Oil Palm Wood Flour Reinforced Epoxidized Natural Rubber Composites: Effects of Filler Content and Size. European Polymer Journal, 33, 1627-1632.

https://doi.org/10.1016/S0014-3057(97)00020-7

[5] Ansarifar, A., Shiah, S.F. and Bennett, M. (2005) Optimizing the Chemical Bonding between Silanised Silica Nanofiller and Natural Rubber and Assessing Its Effects on the Properties of the Rubber. International Journal of Adhesion and Adhesives, 26, 454-463. https://doi.org/10.1016/j.ijadhadh.2005.06.008

[6] Kim, M., Kim, V., Chowdhury, S.R. and Kim, G. (2006) Melt-Compounded Butadiene Rubber Nanocomposites with Improved Mechanical Properties and Abraision Resistance. Journal of Applied Polymer Science, 102, 2062-2066.

https://doi.org/10.1002/app.23738

[7] Igwe, I.O. andEjim, A.A. (2011) Studies on Mechanical and End-Use Properties of Natural Rubber Filled with Snail Shell Powder. Journal of Materials Sciences and Application, 2, 801-809. https://doi.org/10.4236/msa.2011.27109

[8] Zhang, H., Wang, Y., Zhang, L. and Yang, J. (2004) Preparation and Processing of Novel Polymer Materials. Journal of Applied Polymer Science, 97, 844-849. https://doi.org/10.1002/app.21797

[9] Yang, J., Tian, M., Jia, Q., Zhang, L. and Li, X. (2006) Influence of Graphite Particle Size and Shape on the Properties of NBR. Journal of Applied Polymer Science, 102, 4007-4015. https://doi.org/10.1002/app.24844

[10] Zhao, M. and Xiang, Y. (2004) Natural Rubber Vulcanizate Reinforced by Modified Coalshale-Based Fillers. Journal of Applied Polymer Science, 93, 1397-1400. https://doi.org/10.1002/app.20506

[11] Imanah, J.E and Okieimen, F.E. (2004) Studies on the Mechanical Properties of Natural Rubber Reinforced with Agricultural By-Products. Proceedings of 27 th International Conference of Chemical Society of Nigeria, Benin City, 317-322.

[12] Chaiwat, R., Wasaphon, W., Apikiat, S. and Yapoporn, R. (2013) Congo Grass FibreExpoxidized Natural Rubber Composites. Advanced Materials and Resources, 7, 375-378.

[13] Adeosun, B.F. (2002) Mechanical and Rheological Properties of Natural Rubber Composites Reinforced with Agricultural Wastes. Nigerian Journal of Polymer Science and Technology, 1, 58-62.

[14] Imanah, J.E. (2003) Studies in the Utilization of Cocoa Pod Husk and Rubber Seed Shell as Fillers in Natural Rubber Compounds. Unpublished Ph.D. Thesis, Department of Chemistry, University of Benin, Nigeria, 61-310.

[15] Ishak, Z.A.M. and Bakar, A.A. (1995) An Investigation on the Potential of Rice Husk Ash as Filler for Expoxidised Natural Rubber. European Polymer Journal, 31, 259-269. https://doi.org/10.1016/0014-3057(94)00156-1

[16] Egwaikhide, A.P., Okieimen, F.E. and Lawal, U. (2013) Rheologoical and Mechanical Properties of Natural Rubber Compounds Filled with Carbonized Palm Kernel 
Husk and Carbon Black (N330). Science Journal of Chemistry, 1, 50-55. https://doi.org/10.11648/j.sjc.20130105.11

[17] Okoh, B.E., Osabohien, E. and Egboh, S.H.O. (2014) The Reinforcing Potentials of Velvet Tamarind Seed Shell as Filler in Natural Rubber Compounds. International Journal of Biological and Chemical Sciences, 8, 2367-2376. https://doi.org/10.4314/ijbcs.v8i5.39

[18] Eze, I.O. and Igwe, I.O. (2018) Comparison of Some Mechanical Properties of Injection and Extrusion Moulded Pineapple Leaf Powder Filled High Density Polyethylene. European Journal of Advances in Engineering and Technology, 5, 236-243.

[19] Eze, I.O., Igwe, I.O., Nwanonenyi, S.C., Anyanwu, E.E., Ogbobe, O., Obasi, H.C., Ezeamaku, U.L. and Nwachukwu, I. (2017) Effects of Hydrogen Peroxide Treated Pineapple Leaf Powder on Mechanical Properties of High Density Polyethylene Composites. European Journal of Advances in Engineering and Technology, 4, 617-622.

[20] Eze, I.O., Igwe, I.O., Ogbobe, O., Anyanwu, E.E. and Nwachukwu, I. (2016) Mechanical Properties of Pineapple Leaf Powder Filled High Density Polyethylene. International Journal of Engineering and Technologies, 9, 13-19.

https://doi.org/10.18052/www.scipress.com/IJET.9.13

[21] Lopattananon, N., Panawarangkul, K., Sahakaro, K. and Ellis, B. (2007) Performance of Pineapple Leaf Fibre-Natural Rubber Composites: The Effect of Fibre Surface Treatments. Journal of Applied Polymer Science, 102, 1974-1984. https://doi.org/10.1002/app.24584

[22] Goering, H.K. and van Soest, P.J. (1970) Forage Fibre Analysis (Apparatus, Reagents, Procedures and Applicatiions) Agricultural Research Service. USDA, Washington DC.

[23] Liyama, A. and Wallis, N. (1988) Analytical Methods in Wood Chemistry, Pulping and Papermaking. Journal of Science and Engineering, 6, 231-251.

[24] Wang, B., Ponigrahi, S., Tabil, L., Crerar, W., Powell, T., Kolybaba, M. and Sokharisanj, S. (2003) Flax Fibre-Reinforced Thermoplastic Composites. CSAE/ASAE Annual International Meeting, Furgo, 3-4 October 2003.

[25] Asore, E.J. (2000) An Introduction to Rubber Technology. Joseg Books Ltd., Benin City, 2-4.

[26] Broonstra, B.B. (1984) Reinforcement by Fillers. In: Mortron, M., Ed., Rubber Technology, 2nd Edition, Van Nostrand Co., New York, 56-108.

[27] Bledzki, A.K. and Gassan, J. (1999) Composites Reinforced with Cellulose Based Fibres. Progress in Polymer Science, 24, 221-274. https://doi.org/10.1016/S0079-6700(98)00018-5

[28] Spinace, M.A.S., Lambert, C.S., Fermoselli, K.K.G. and Depaoli, M.A. (2009) Characterization of Lignocellulosic Curana Fibres. Carbohydrate Polymer, 77, 47-53. https://doi.org/10.1016/j.carbpol.2008.12.005

[29] Khalil, A.H.P.S., Alwani, S.M. and Omar, M.A.K. (2006) Chemical Composition, Anatomy, Lignin Distribution and Cell Wall Structure of Malaysia Plant Waste Fibres. BioResourses, 1, 220-232.

[30] Rahman, A. (2011) Study on Modified Pineapple Leaf Fibre. Journal of Textile and Apparel, Technology and Management, 7, 1-16.

[31] Jacob, M., Thomas, S. and Varughese, K.T. (2004) Mechanical Properties of Sisal/Oil Palm Hybrid Fibre-Reinforced Natural Rubber Composites. Composite Science and Technology, 64, 955-965. 
https://doi.org/10.1016/S0266-3538(03)00261-6

[32] Ismail, H., Shuhelmy, S. and Edyham, M.R. (2002) The Effects of a Sliane Coupling Agent on Curing Characteristics and Mechanical Properties of Bamboo Filled Natural Rubber Composites. European Polymer Journal, 38, 39-47.

https://doi.org/10.1016/S0014-3057(01)00113-6

[33] Iyasele, J.U. and Okieimen, F.E. (2004) Cure Characteristics and Rheological Properties of Melon Seed Shell Filled Natural Rubber. Proceedings of the 27 th Internal Conference of Chemical Society of Nigeria, Benin City, 272-276.

[34] Hepbum, C. and Blow, C.M. (1971) Rubber Technology and Manufacture. 3rd Edition, Butterworth Publishing, 188.

[35] Rivin, D. (1963) Polymer-Filler Interaction in Rubber Reinforcement. Rubber Chemistry and Technology, 36, 729. https://doi.org/10.5254/1.3539604

[36] Mohamed, N., Maditar, A., Ghazali, M.J., Muhd, D. and Azhari, C.H. (2008) The Effect of Filler on Epoxidized Natural Rubber-Alumina Nanoparticle Composites. European Journal of Science and Research, 24, 538-547.

[37] Parkinson, D. (1957) Reinforcement of Rubbers. Lakeman and Co., London, 12.

[38] Wagner, M.P. (1976) Silicon Rubber Compositions. Incorporating Silicone-Treated Carbon Black, 50, 342. 